\title{
Comparison of Percutaneous Coronary Intervention and Optimal Medical Therapy on Outcomes in Patients with Chronic Coronary Total Occlusion
}

\author{
Fuliang Zhou \\ Department of Cardiology, The First affiliated hospital of China Medical University, Shenyang, Liaoning \\ Lufan Sun \\ Department of Cardiology, The First affiliated hospital of China Medical University, Shenyang, Liaoning \\ Qiushuang Liu \\ Department of Cardiology, The First affiliated hospital of China Medical University, Shenyang, Liaoning \\ Nan Wu \\ Department of Cardiology, The First affiliated hospital of China Medical University, Shenyang, Liaoning \\ Dalin Jia ( $\nabla$ jdl2001@263.net) \\ Department of Cardiology, The First affiliated hospital of China Medical University, Shenyang, Liaoning
}

\section{Research Article}

Keywords: CTO, PCl, medical therapy, meta-analysis

Posted Date: September 3rd, 2021

DOI: https://doi.org/10.21203/rs.3.rs-778915/v1

License: @) (7) This work is licensed under a Creative Commons Attribution 4.0 International License. Read Full License 


\section{Abstract}

Background: Nowadays the optimal strategy for patients with chronic total occlusion (CTO) has not been well established. This meta-analysis aims to evaluate effect of $\mathrm{PCl}$ and optimal medical therapy (OMT) on clinical outcomes in these patients.

Methods: Pubmed, Embase and Cochrane Library were searched for studies about patients who had CTO and received PCI or medical therapy as initial strategy, from inception to February 2020. Results of pooled analysis were expressed by risk ratios (RR) and $95 \%$ confidence intervals (Cl), which were calculated by random effects or fixed effects model according to heterogeneity. Sensitivity analysis was performed by removing one study a time. Funnel plot and Egger's value were used to appraise publication bias. All analysis were calculated by Revmen5.0 and Stata15.0 software.

Results: Total 11studies were included in our meta-analysis, 4 RCTs and 7 observation studies using PSM. Total 5664 patients with CTO were enrolled. 2904 patients underwent $\mathrm{PCl}$ and 2760 patients received OMT. Pooled analysis indicated that compared with OMT, PCl was associated with lower risk of cardiac death (RR $0.59,95 \% \mathrm{Cl} 0.45-0.77, \mathrm{P}<0.001)$. However, there was no significant discrimination in MACE (RR $0.83,95 \% \mathrm{Cl} 0.64-1.06, \mathrm{P}=0.14)$, myocardial infarction ( $R R 0.98,95 \% \mathrm{Cl} 0.78-1.24, \mathrm{P}=0.86$ ), repeat revascularization ( $\mathrm{RR} 0.95,95 \% \mathrm{Cl} 0.71-1.25, \mathrm{P}=0.71$ ), and stroke (RR $0.62,95 \% \mathrm{Cl} 0.29-1.34, \mathrm{P}=0.22)$. Subanalysis by ethnicity showed that PCI was associated with lower incidence of MACE compared with OMT in West European (RR 0.48, 95\% Cl 0.28-0.84, $\mathrm{P}=0.01$ ), but not in East Asian (RR 0.94,95\% Cl 0.77-1.16, P=0.58).

Conclusions: Compared with OMT, PCl is associated with lower risk of cardiac death. However, there was no significant difference in MACE, MI, repeated revascularization and stroke. Sub-analysis indicates that $\mathrm{PCl}$ is favor of West European.

\section{Background:}

Chronic coronary total occlusion (CTO) is defined as TIMI flow grade 0 in a coronary artery lasting over 3 months. Prevalence of CTO in patients undergoing $\mathrm{PCl}$ is around $18 \sim 30 \%{ }^{[1-3]}$,but this data is increasing with the popularity of angiography. Some studies indicate that patients with CTO are associated with worse outcomes ${ }^{[4,5]}$. Presence of CTO in STEMI patients increase nearly 4 times cardiovascular mortality ${ }^{[4]}$. Besides, CTO in stable coronary heart disease is related to greater mortality ${ }^{[5]}$ and more ventricular arrhythmia occurrence ${ }^{[6]}$. Percutaneous coronary intervention (PCI) of CTO is a challenge for interventional cardiologists with low successful revascularization rate more procedural complications, greater radiation exposure ${ }^{[7]}$, and high cost ${ }^{[8]}$. In real word, only a small proportion of patients receive PCI therapy ${ }^{[9]}$. NCDR register showed about $4 \%$ CTO patients undergoing PCI ${ }^{[7]}$. Up to data, the treatment strategies of CTO are debated. According to 2018 ESC guideline ${ }^{[10]}$, PCI for CTO patients carries a class lla and level of evidence $\mathrm{B}$ recommendation. However, recently some studies indicate that successful PCl of CTO would reduce mortality ${ }^{[11-14]}$, but majority of these studies just compare successful and failed PCI among CTO patients. While data about comparison of $\mathrm{PCl}$ and optimal medical therapy (OMT) are scant, and conclusions remain vague. Some studies suggest that compared with OMT, PCI for СTO patients relieve angina symptoms, improve life quality ${ }^{[15]}$ and reduce mortality ${ }^{[16,17]}$. To the contrast, other studies are disagreed with these outcomes ${ }^{[18-21]}$. Therefore, this systemic review and meta-analysis aims to compare the outcomes of PCl versus OMT as strategy for CTO and further offer more comprehensive understandings for physicians.

\section{Methods:}

\section{Search strategy}

This meta-analysis was conducted according to the PRISMA statements ${ }^{[22]}$. We searched studies about comparison of PCI versus medical therapy in patients with CTO in Pubmed, Embase, Cochrane Library databases separately, from inception to February 2020.Langue was restricted to English. Following key terms

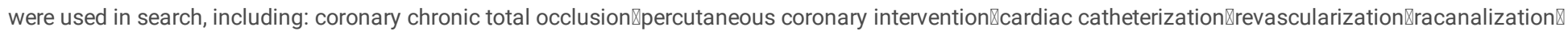
conservational therapy $₫$ medical therapy. The search formula is provided in detail in the supplement 1 .

Studies fulfilled the following criteria can be included in this meta-analysis: (1) Randomized controlled study or observation study;(2) observation study must use the propensity score matched (PSM)analysis;(3) studies compared different strategies of PCl versus OMT;(4) studies include clinical outcomes. Studies were excluded:(1) patients with no CTO;(2) compare successful and failed PCl;(3) patients with acute myocardial infarction concurrent CTO in non-IRA; (4) observation not use PSM analysis;(5) studies in other langue.

\section{Data extraction:}

Two reviewers separately extracted detailed data from enrolled studies including: first author; publication year; ethnicity; sample size; follow up duration; age; sex; hypertension; diabetes mellitus; dyslipidemia; smoking; previous Ml; previous PCl; previous CABG; CKD; stroke; LVEF (\%); location of CTO using prespecified data extraction form. Disagreement was solved by consensus.

Outcomes pooled in our meta-analysis include MACE; cardiac death; myocardial infarction (MI); repeat revascularization; stroke. MACE was defined by each study.

\section{Quality assessment of studies]}


Cochrane collaboration's risk of bias tool was used for assessing RCT included in our study, including: Random sequence generation; Allocation concealment; Blinding of participants and personnel; Blinding of outcome assessment; Incomplete outcome data; Selective reporting; Other bias.

Other observation studies were assessed by The Newcastle-Ottawa Scale ${ }^{[23]}$, including Representativeness of the exposed cohort; Selection of the nonexposed cohort; Ascertainment of exposure; Outcome of interest not present at start of study; Comparability; Assessment of outcome; Adequacy of duration of follow-up; Adequacy of completeness of follow-up.

\section{Statistic analysis}

All analysis was performed by Revmen5.0 and Stata15.0 software. Pooled outcomes were presented by Risk ratio (RR) and $95 \%$ confidence interval (CI). Heterogeneity of the summary study was assessed by Cochrane's $Q$ test and $I^{2}$ statistic. If $p$ value of Cochrane's $Q$ test $<0.1$ and $I^{2}>50 \%$, we consider existence of heterogeneity. When heterogeneity exist, pooled RR was calculated by the random effect model, otherwise, RR was calculated by fixed effect model. Sensitivity analysis was carried to explore the source of heterogeneity by sequentially removing one study a time. Visual funnel plots were used to evaluate publication bias. Egger's test was conducted to assess for publication bias. If $p$ value of Egger's test $<0.1$, publication bias was considered to exist. All tests were two-tailed, significance was considered if $\mathrm{p}$ value $<0.05$.

\section{Results:}

\section{Search results and baseline characteristics of patients}

Study selection procedure was detailedly proscribed in Fig1. Total 641 studies were found after excluding the duplicate records. 519 studies were excluded after reading titles and abstracts,. 111 of the remained 122 studies were excluded after reading full text. Eventually 11 studies were identified in our metaanalysis, which involves 4 RCTs and 7 observation studies. 5 of 11 studies were conducted in Europe, 3 were in China and 3 were in Korea. Given to the ethnic difference, 5 of all are west European while 6 are east Asian. Baseline characteristics of all studies were available except the IMPACTOR-CTO trial. The baseline characteristics of IRCTO trial were not analysed by PSM method, while clinical outcomes were analysed by PSM method. Our analysis includes total 5664 CTO patients, of whom 2904 patients received PCI therapy and 2760 patients received OMT therapy. The baseline characteristics of included studies were showed in Table1.

Table 1

Baseline characteristics in PCl vs OMT arms

\begin{tabular}{|c|c|c|c|c|c|c|c|c|c|c|c|}
\hline \multirow[t]{2}{*}{ Study ID } & \multirow[t]{2}{*}{ Years } & \multirow[t]{2}{*}{ Ethicity } & \multicolumn{2}{|c|}{$\begin{array}{l}\text { Number of } \\
\text { Population }\end{array}$} & \multirow{2}{*}{$\begin{array}{l}\text { Follow } \\
\text { up } \\
\text { (Months) }\end{array}$} & \multicolumn{2}{|l|}{ Age(years) } & \multicolumn{2}{|l|}{ Male } & \multicolumn{2}{|c|}{ Hypertension } \\
\hline & & & $\mathrm{PCl}$ & OMT & & $\mathrm{PCl}$ & OMT & $\mathrm{PCl}$ & OMT & $\mathrm{PCl}$ & OMT \\
\hline Choi SY & 2017 & Asian & 158 & 158 & $60 M$ & $64 \pm 9$ & $64 \pm 11$ & $\begin{array}{l}117 \\
(74.1)\end{array}$ & $\begin{array}{l}113 \\
(71.5)\end{array}$ & $\begin{array}{l}107 \\
(67.7)\end{array}$ & 111(70.3) \\
\hline Lee SW & 2018 & Asian & 417 & 398 & $36 \mathrm{M}$ & $62.2 \pm 10.2$ & $62.9 \pm 9.9$ & $344(83.3)$ & $319(81.6)$ & $262(63.4)$ & $238(60.9)$ \\
\hline Yang JH & 2016 & Asian & 533 & 533 & $45.8 \mathrm{M}$ & $63.5 \pm 10.3$ & $64.5 \pm 11.4$ & $\begin{array}{l}425 \\
(79.7)\end{array}$ & $\begin{array}{l}419 \\
(78.6)\end{array}$ & $\begin{array}{l}348 \\
(65.3)\end{array}$ & $\begin{array}{l}350 \\
(65.7)\end{array}$ \\
\hline Gao L & 2018 & Asian & 80 & 80 & $47.2 \mathrm{M}$ & $64.76 \pm 9.58$ & $\begin{array}{l}64.55 \pm \\
11.24\end{array}$ & $56(70)$ & $58(72.5)$ & $54(67.5)$ & $55(68.8)$ \\
\hline Gao L* & 2019 & Asian & 286 & 286 & $43.2 \mathrm{M}$ & $63.3 \pm 9.6$ & $63.4 \pm 10.5$ & $\begin{array}{l}207 \\
(72.4)\end{array}$ & $\begin{array}{l}217 \\
(75.9)\end{array}$ & $\begin{array}{l}199 \\
(69.6)\end{array}$ & $\begin{array}{l}188 \\
(65.7)\end{array}$ \\
\hline Yan YF & 2019 & Asian & 118 & 118 & $45 \mathrm{M}$ & $\begin{array}{l}62.00(54.50- \\
67.00)\end{array}$ & $\begin{array}{l}58.00(51.00- \\
68.75)\end{array}$ & $90(76.3)$ & 93 (78.8) & $84(71.2)$ & 79 (66.9) \\
\hline Choo EH & 2018 & Asian & 264 & 264 & $26.4 \mathrm{M}$ & $61.5 \pm 09.8$ & $61.5 \pm 10.5$ & $\begin{array}{l}199 \\
(75.4)\end{array}$ & $\begin{array}{l}201 \\
(76.1)\end{array}$ & $\begin{array}{l}156 \\
(59.1)\end{array}$ & $\begin{array}{l}159 \\
(60.2)\end{array}$ \\
\hline Obedinskiy & 2018 & $\begin{array}{l}\text { West- } \\
\text { European }\end{array}$ & 39 & 33 & $1 \mathrm{M}$ & $\mathrm{N}$ & $\mathrm{N}$ & $\mathrm{N}$ & $\mathrm{N}$ & $\mathrm{N}$ & $\mathrm{N}$ \\
\hline Werner GS & 2018 & $\begin{array}{l}\text { West- } \\
\text { European }\end{array}$ & 259 & 137 & $12 \mathrm{M}$ & $65.2 \pm 9.7$ & $64.7 \pm 9.9$ & $\begin{array}{l}215 \\
(83.0)\end{array}$ & $\begin{array}{l}118 \\
(86.1)\end{array}$ & $\begin{array}{l}189 \\
(73.0)\end{array}$ & 98 (71.5) \\
\hline Ladwiniec A & 2015 & $\begin{array}{l}\text { West- } \\
\text { European }\end{array}$ & 294 & 294 & $60 \mathrm{M}$ & $64.3 \pm 10.0$ & $63.9 \pm 10.2$ & $\begin{array}{l}220 \\
(74.8)\end{array}$ & $\begin{array}{l}220 \\
(74.8)\end{array}$ & $\begin{array}{l}159 \\
(54.1)\end{array}$ & $\begin{array}{l}157 \\
(53.4)\end{array}$ \\
\hline $\begin{array}{l}\text { Mashayekhi } \\
\text { K }\end{array}$ & 2018 & $\begin{array}{l}\text { West- } \\
\text { European }\end{array}$ & 101 & 104 & $12 \mathrm{M}$ & $65(57-72)$ & $68(61-74)$ & $91(90.1)$ & $90(86.5)$ & $81(80.2)$ & 93 (89.4) \\
\hline
\end{tabular}




\begin{tabular}{|c|c|c|c|c|c|c|c|c|c|c|c|c|}
\hline \multirow[t]{2}{*}{ Study ID } & \multicolumn{2}{|c|}{ Diabetes Mellitus } & \multicolumn{2}{|c|}{ Dyslipidemia } & \multicolumn{2}{|l|}{ Smoking } & \multicolumn{2}{|c|}{ Previous MI } & \multicolumn{2}{|c|}{ Previous $\mathrm{PCl}$} & \multicolumn{2}{|c|}{ Previous CAE } \\
\hline & $\mathrm{PCl}$ & OMT & $\mathrm{PCl}$ & OMT & $\mathrm{PCl}$ & OMT & $\mathrm{PCl}$ & OMT & $\mathrm{PCl}$ & OMT & $\mathrm{PCl}$ & ON \\
\hline Choi SY & $\begin{array}{l}78 \\
(49.4)\end{array}$ & 72 (45.6区 & $51(32.3)$ & $49(31.0)$ & $79(50.0)$ & $94(59.5)$ & $\mathrm{N}$ & $\mathrm{N}$ & $\mathrm{N}$ & $\mathrm{N}$ & $\mathrm{N}$ & $\mathrm{N}$ \\
\hline Lee SW & $\begin{array}{l}132 \\
(32.0)\end{array}$ & 134(34.3) & $249(60.3)$ & $217(55.5)$ & $125(30.3)$ & 102(26.1) & $45(10.9)$ & $34(8.7)$ & 64(15.5) & 75(19.2) & $4(1.0)$ & $5(1$ \\
\hline Yang JH & $\begin{array}{l}252 \\
(47.3)\end{array}$ & $242(45.4)$ & $\begin{array}{l}143 \\
(26.8)\end{array}$ & $139(26.1)$ & $\begin{array}{l}168 \\
(31.5)\end{array}$ & $156(29.3)$ & $\begin{array}{l}146 \\
(27.4)\end{array}$ & $\begin{array}{l}144 \\
(27.0)\end{array}$ & $\begin{array}{l}142 \\
(26.6)\end{array}$ & $\begin{array}{l}142 \\
(26.6)\end{array}$ & $\mathrm{N}$ & $\mathrm{N}$ \\
\hline Gao L & $24(30)$ & $22(27.5)$ & $42(52.5)$ & $41(51.2)$ & $32(40)$ & $35(43.8)$ & $21(26.3)$ & $20(25.0)$ & $5(6.3)$ & $10(12.5)$ & $\mathrm{N}$ & $\mathrm{N}$ \\
\hline Gao L* & $\begin{array}{l}107 \\
(37.4)\end{array}$ & $\begin{array}{l}103 \\
(36.0)\end{array}$ & $\begin{array}{l}213 \\
(74.5)\end{array}$ & $210(73.4)$ & $\begin{array}{l}112 \\
(39.2)\end{array}$ & $111(38.8)$ & $\begin{array}{l}111 \\
(38.8)\end{array}$ & $\begin{array}{l}127 \\
(44.4)\end{array}$ & $35(12.2)$ & $40(14.0)$ & $\mathrm{N}$ & $\mathrm{N}$ \\
\hline Yan YF & $\begin{array}{l}118 \\
\text { ه100\%囚 }\end{array}$ & $\begin{array}{l}118 \\
\square 100 \% \bigotimes\end{array}$ & $59(50.0)$ & $61(51.7)$ & 68 (57.6) & $66(55.9)$ & $66(55.9)$ & $\begin{array}{l}67 \\
(56.8)\end{array}$ & $\begin{array}{l}50 \\
(42.4)\end{array}$ & $\begin{array}{l}57 \\
(48.3)\end{array}$ & $\mathrm{N}$ & $\mathrm{N}$ \\
\hline Choo EH & $\begin{array}{l}117 \\
(44.3)\end{array}$ & $\begin{array}{l}121 \\
(45.8)\end{array}$ & $\mathrm{N}$ & $\mathrm{N}$ & $71(26.9)$ & $64(24.2)$ & $\mathrm{N}$ & $\mathrm{N}$ & $\mathrm{N}$ & $\mathrm{N}$ & $\mathrm{N}$ & $\mathrm{N}$ \\
\hline Obedinskiy & $\mathrm{N}$ & $\mathrm{N}$ & $\mathrm{N}$ & $\mathrm{N}$ & $\mathrm{N}$ & $\mathrm{N}$ & $\mathrm{N}$ & $\mathrm{N}$ & $\mathrm{N}$ & $\mathrm{N}$ & $\mathrm{N}$ & $\mathrm{N}$ \\
\hline Werner GS & $\begin{array}{l}85 \\
\otimes 32.8 \square\end{array}$ & $40 \rrbracket 29.2 \rrbracket$ & $\begin{array}{l}210 \\
(81.1)\end{array}$ & $111(81.0)$ & $\begin{array}{l}190 \\
(73.4)\end{array}$ & $92(67.2)$ & 59 (22.8) & $\begin{array}{l}25 \\
(18.3)\end{array}$ & $\begin{array}{l}145 \\
(56.0)\end{array}$ & 71 (51.8) & $\begin{array}{l}34 \\
(13.1)\end{array}$ & $\begin{array}{l}10 \\
(7 .:\end{array}$ \\
\hline Ladwiniec A & $\begin{array}{l}62 \\
(21.1)\end{array}$ & $53(18.0)$ & $\begin{array}{l}146 \\
(49.7)\end{array}$ & $\begin{array}{l}135 \\
(45.9)\end{array}$ & 56 (19.1) & $62(21.1)$ & $\begin{array}{l}151 \\
(51.4)\end{array}$ & $\begin{array}{l}143 \\
(48.6)\end{array}$ & $18(6.1)$ & $24(8.2)$ & $\mathrm{N}$ & $\mathrm{N}$ \\
\hline $\begin{array}{l}\text { Mashayekhi } \\
\text { K }\end{array}$ & $\begin{array}{l}32 \\
(31.6)\end{array}$ & $31(29.8)$ & $\mathrm{N}$ & $\mathrm{N}$ & $23(22.8)$ & $21(20.2)$ & 39 (38.6) & $\begin{array}{l}38 \\
(36.5)\end{array}$ & $28(27.7)$ & $\begin{array}{l}33 \\
(31.7)\end{array}$ & $\begin{array}{l}12 \\
(11.9)\end{array}$ & $\begin{array}{l}14 \\
(1 \Xi\end{array}$ \\
\hline
\end{tabular}

\begin{tabular}{|c|c|c|c|c|c|c|c|c|c|c|c|c|}
\hline \multirow[t]{2}{*}{ Study ID } & \multicolumn{2}{|l|}{ CKD } & \multicolumn{2}{|l|}{ Stroke } & \multicolumn{2}{|l|}{ LVEF(\%) } & \multicolumn{2}{|l|}{ LAD } & \multicolumn{2}{|l|}{ LCX } & \multicolumn{2}{|l|}{ RCA } \\
\hline & $\mathrm{PCl}$ & OMT & $\mathrm{PCl}$ & OMT & $\mathrm{PCl}$ & OMT & $\mathrm{PCl}$ & OMT & $\mathrm{PCl}$ & OMT & $\mathrm{PCl}$ & OMT \\
\hline Choi SY & $14(8.9)$ & $13(8.2)$ & $\begin{array}{l}21 \\
(13.3)\end{array}$ & $\begin{array}{l}17 \\
(10.8)\end{array}$ & $50 \pm 12$ & $50 \pm 12$ & 52 (32.9) & $49(31)$ & $45(28.5)$ & $\begin{array}{l}43 \\
(27.2)\end{array}$ & $73(46.2)$ & $\begin{array}{l}78 \\
(49.4)\end{array}$ \\
\hline Lee SW & $6(1.5)$ & $5(1.3)$ & $\begin{array}{l}29 \\
(7.0)\end{array}$ & $\begin{array}{l}31 \\
(7.9)\end{array}$ & $57.3 \pm 9.8$ & $57.6 \pm 9.1$ & $185(44.8)$ & $\begin{array}{l}163 \\
(41.7)\end{array}$ & $42(10.2)$ & $\begin{array}{l}42 \\
(10.7)\end{array}$ & $186(45.0)$ & $\begin{array}{l}186 \\
(47.6)\end{array}$ \\
\hline Yang JH & $46(8.6)$ & $47(8.8)$ & $\begin{array}{l}47 \\
(8.8)\end{array}$ & $\begin{array}{l}45 \\
(8.4)\end{array}$ & $55.6 \pm 11.9$ & $55.7 \pm 11.7$ & $\begin{array}{l}152 \\
(28.5)\end{array}$ & $\begin{array}{l}146 \\
(27.4)\end{array}$ & $\begin{array}{l}170 \\
(31.9)\end{array}$ & $\begin{array}{l}174 \\
(32.6)\end{array}$ & $\begin{array}{l}288 \\
(54.0)\end{array}$ & $\begin{array}{l}293 \\
(55.0)\end{array}$ \\
\hline Gao L & $12(15.0)$ & 12(15.0) & $7(8.8)$ & $8(10.0)$ & $\begin{array}{l}53.70 \pm \\
8.29\end{array}$ & $\begin{array}{l}53.63 \pm \\
7.21\end{array}$ & $30(36.1)$ & $26(31.3)$ & 19(22.9) & $22(26.5$ & $34(41.0)$ & $\begin{array}{l}35 \\
(42.2)\end{array}$ \\
\hline Gao L* & $19(6.6)$ & $21(7.3)$ & $\mathrm{N}$ & $\mathrm{N}$ & $54.6 \pm 7.8$ & $53.6 \pm 8.2$ & $\begin{array}{l}112 \\
(39.2)\end{array}$ & $\begin{array}{l}103 \\
(36.0)\end{array}$ & 65 (22.7) & $\begin{array}{l}60 \\
(21.0)\end{array}$ & $\begin{array}{l}132 \\
(46.2)\end{array}$ & $\begin{array}{l}146 \\
(51.0)\end{array}$ \\
\hline Yan YF & $4(3.4)$ & $4(3.4)$ & $7(5.9)$ & $6(5.1)$ & $\begin{array}{l}62.00 \\
(57.00- \\
68.00)\end{array}$ & $\begin{array}{l}61.50 \\
(53.10- \\
67.00)\end{array}$ & $33(28.0)$ & $\begin{array}{l}36 \\
(30.5)\end{array}$ & $31(26.3)$ & $\begin{array}{l}33 \\
(28.0)\end{array}$ & $54(45.8)$ & $\begin{array}{l}49 \\
(41.5)\end{array}$ \\
\hline Choo EH & $26(9.8)$ & $26(9.8)$ & $\begin{array}{l}25 \\
(9.5)\end{array}$ & $\begin{array}{l}24 \\
(9.1)\end{array}$ & $\begin{array}{l}54.8 \pm \\
11.3\end{array}$ & $\begin{array}{l}53.6 \pm \\
12.3\end{array}$ & $84(31.8)$ & $80(30.3)$ & $66(25.0)$ & $\begin{array}{l}72 \\
(27.3)\end{array}$ & $\begin{array}{l}124 \\
(47.0)\end{array}$ & $\begin{array}{l}118 \\
(44.7)\end{array}$ \\
\hline Obedinskiy & $\mathrm{N}$ & $\mathrm{N}$ & $\mathrm{N}$ & $\mathrm{N}$ & $\mathrm{N}$ & $\mathrm{N}$ & $\mathrm{N}$ & $\mathrm{N}$ & $\mathrm{N}$ & $\mathrm{N}$ & $\mathrm{N}$ & $\mathrm{N}$ \\
\hline Werner GS & $\mathrm{N}$ & $\mathrm{N}$ & $\mathrm{N}$ & $\mathrm{N}$ & $54.5 \pm 10.8$ & $55.7 \pm 10.8$ & $66(25.5)$ & $38(27.0)$ & 28(10.8) & $\begin{array}{l}22 \\
(15.6)\end{array}$ & $\begin{array}{l}165 \\
(63.7)\end{array}$ & $\begin{array}{l}81 \\
(57.4)\end{array}$ \\
\hline Ladwiniec A & $\begin{array}{l}59 \\
(20.1)\end{array}$ & $64(21.8)$ & $\begin{array}{l}17 \\
(5.8)\end{array}$ & $\begin{array}{l}20 \\
(6.8)\end{array}$ & $\begin{array}{l}213 \\
(72.5)\end{array}$ & $\begin{array}{l}220 \\
(74.8)\end{array}$ & $\mathrm{N}$ & $\mathrm{N}$ & $\mathrm{N}$ & $\mathrm{N}$ & $\mathrm{N}$ & $N$ \\
\hline $\begin{array}{l}\text { Mashayekhi } \\
\text { K }\end{array}$ & $\mathrm{N}$ & $\mathrm{N}$ & $\begin{array}{l}5 \\
(5.0)\end{array}$ & $9(8.6)$ & $\mathrm{N}$ & $\mathrm{N}$ & $23(22.8)$ & $17(16.3)$ & $20(19.8)$ & $\begin{array}{l}16 \\
(15.4)\end{array}$ & $58(57.4)$ & $\begin{array}{l}71 \\
(68.3)\end{array}$ \\
\hline
\end{tabular}

Data are expressed as mean \pm SD or absolute numbers (\%).

MI: myocardial infarction; PCl:percutaneous coronary intervention; OMT: optimal medical therapy; CABG: coronary artery bypass grafting; CKD: chronic kidney disease; LVEF: left ventricular ejection fraction; LAD: left anterior descending artery; LCX: left circumflex artery; RCA: right coronary artery; N: null.

CKD in Ladwiniec $A$ et al study is CKD $\geq 3$ stage, LVEF defined in Ladwiniec $A$ et al study is $\geq 50 \%$

Quality assessment of 4 RCTs were low-to-moderate quality, while, 7 observation studies were moderate quality. Detailed description was showed in supplement 2 . 


\subsection{Comparison of PCI vs. OMT in MACE}

There were 10 studies reporting the MACE event. Pooled analysis showed that patients with CTO who received PCI had no significant difference in risk of MACE compared with OMT (RR $0.83,95 \% \mathrm{Cl} 0.64-1.06, \mathrm{P}=0.14$ ). However, there was a discrepancy in ethnicity. Sub-analysis by ethnicity indicated that $\mathrm{PCl}$ is associated with lower incidence of MACE compared with OMT in west European (RR 0.48, 95\% Cl 0.28-0.84, P=0.01), but not in east Asian (RR 0.94, 95\% Cl 0.77-1.16, P=0.58). Shown in Fig2.

\subsection{Comparison of PCl vs. OMT in cardiac death}

There were 9 studies reporting the cardiac death event. Pooled analysis indicated that compared with OMT, PCI had a lower risk of cardiac death in patients with CTO (RR 0.59, 95\% Cl 0.45-0.77, P<0.001). Result of sub-analysis by ethnicity was in consistence with the main result. However, there was more reduction risk of cardiac death in west European compared with east Asian (east Asian: RR0.67, 95\% Cl 0.49-0.90, P=0.009; west European: RR0.40, 95\% Cl 0.22-0.71, $\mathrm{P}=0.002)$. Shown in Fig3.

\subsection{Comparison of $\mathrm{PCl}$ vs. OMT in myocardial infarction}

There were 10 studies reporting outcomes of myocardial infarction. When pooled analysis of all studies, we found that there was no significant difference between $\mathrm{PCl}$ and OMT in terms of myocardial infarction (RR $0.98,95 \% \mathrm{Cl} 0.78-1.24, \mathrm{P}=0.86$ ). Result of sub-analysis according to ethnicity conformed with main results (east Asian: RR 1.13,95\% Cl 0.84-1.51, P=0.42; west European: RR 0.75,95\% Cl 0.51-1.12, P=0.16). Shown in Fig4.

\subsection{Comparison of PCI vs. OMT in repeated revascularization}

Outcomes of revascularization were reported in 10 studies. Pooled analysis illustrated that there was no significant difference between PCI and OMT regarding repeated revascularization ( $R R 0.95,95 \% \mathrm{Cl} 0.71-1.25, \mathrm{P}=0.71)$. Sub-analysis showed that whatever west European or east $A$ sian, risk of revascularization is similar between $\mathrm{PCl}$ and OMT (east Asian: RR 1.08, 95\% Cl 0.81-1.45, P=0.59; west European: $\mathrm{RR} 0.58,95 \% \mathrm{Cl} 0.30-1.13, \mathrm{P}=0.11$ ). Shown in Fig5

\subsection{Comparison of PCl vs. OMT in stroke}

There were 4 out of 11 studies report outcomes of stroke. Pooled analysis demonstrated that there were no significant difference between PCl and OMT in terms of stroke (RR $0.62,95 \% \mathrm{Cl} 0.29-1.34, \mathrm{P}=0.22$ ). Result of sub-analysis by ethnicity is similar to main results (east $\mathrm{Asian}$ : $\mathrm{RR} 0.64,95 \% \mathrm{Cl} 0.26-1.56$, $\mathrm{P}=0.33$; west European: RR 0. 55, 95\% Cl 0.11-2.69, P=0.46). Shown in Fig6.

\section{Heterogeneity, sensitivity analysis and Publication bias}

There was significant heterogeneity in MACE and repeat revascularization with $\mathrm{I}^{2}$ was $64 \%$ and $55 \%$ correspondingly. We conducted a sensitivity analysis by removing one study a time to locate the origin of heterogeneity. We found that pooled RR of MACE was dramatically changed after removing Gao (2018) study (RR0.78, 95\% Cl 0.62-0.98, $\mathrm{P}=0.04$ ). AS for repeat revascularization, there was no significant change in the overall RR. For significant heterogeneity existed in MACE, we performed a subgroup analysis by ethnicity. And we found that significant heterogeneity still existed in Asian ( $I^{2}$ of MACE and Revascularization was $54 \%$ and $55 \%$ separately in east Asian), but no significant heterogeneity in west European ( $I^{2}$ of MACE and Revascularization was $34 \%$ and $42 \%$ separately in west European).

There no publication bias measured by Egger's value and funnel plots in our analysis. Detailed has been shown in Table2 and Figure7.

Table2. Test of association, Heterogeneity analysis and Publication bias

\begin{tabular}{|c|c|c|c|c|c|c|c|c|}
\hline \multirow[b]{2}{*}{ Outcome } & \multirow[b]{2}{*}{$\mathrm{N}$} & \multicolumn{3}{|c|}{ Test of association } & \multicolumn{3}{|c|}{ Heterogeneity analysis } & \multirow{2}{*}{$\begin{array}{l}\text { Publication bias } \\
\text { Egger's P }\end{array}$} \\
\hline & & RR $(95 \% \mathrm{Cl})$ & $P$ value & Model & $\mathrm{Q}$ value & $P$ value & $\mathrm{I}^{2}(\%)$ & \\
\hline MACE & 10 & $0.83(0.64-1.06)$ & 0.14 & $\mathrm{R}$ & 25.11 & 0.003 & $64 \%$ & 0.952 \\
\hline Cardiac Death & 9 & $0.59(0.45-0.77)$ & 0.0001 & $\mathrm{~F}$ & 8.05 & 0.43 & $1 \%$ & 0.918 \\
\hline Myocardial Infarction & 10 & $0.98(0.78-1.24)$ & 0.86 & $\mathrm{~F}$ & 14.1 & 0.12 & $36 \%$ & 0.761 \\
\hline Repeat Revascularization & 10 & $0.95(0.71-1.25)$ & 0.71 & $\mathrm{R}$ & 19.85 & 0.02 & $55 \%$ & 0.109 \\
\hline Stroke & 4 & $0.62(0.29-1.34)$ & 0.22 & $\mathrm{~F}$ & 0.74 & 0.86 & $0 \%$ & 0.73 \\
\hline
\end{tabular}

R: random effect model; F: fixed effect model 


\section{Discussion:}

This meta-analysis demonstrated that compared with OMT, PCI was associated with lower cardiac death in patients with CTO. However, there was no significant difference between $\mathrm{PCl}$ and $\mathrm{OMT}$ therapy regarding MACE, MI, repeat revascularization and stroke. Subgroup analysis according to ethnicity indicated that patients with CTO who received PCl therapy could reduce 52\% MACE in West European, but not in East Asian. As for cardiac death, PCI could decrease about $60 \%$ cardiac death in west European while just $30 \%$ in east Asian when compared with OMT.

As showed by COURAGE trial[ ${ }^{[24]}$ that there was no reduction in mortality and MI incidence for CTO patients with stable coronary artery disease who accepted $\mathrm{PCl}$ strategy, while PCl could provide a notable improvement in health status. Besides, results from another study indicated that compared with OMT, PCI had no association with lower mortality and cardiac death, but CTO patients were excluded in this study ${ }^{[25]}$. That was different with our study population. Recently a meta-analysis demonstrated successful PCl could reduce long-term mortality and the risks of $\mathrm{MI}, \mathrm{MACE}$, and CABG, compared with failed PCI for patients with $\mathrm{CTO}^{[26]}$. As we all known, СTO revascularization procedure is complex with low successful rate. There were more peri-operative complications for failed $\mathrm{PCI}^{[7,27]}$. Data from two studies suggested that $\mathrm{PCl}$ failure was an independent predictor of worse outcomes ${ }^{[28,29]}$. Apart from that, standard antiplatelet therapy after successful PCI may contribute to better prognosis. These may result in overestimation for the benefit of successful PCl.

A recent meta-analysis ${ }^{[30]}$, including 5 observation studies, compared $\mathrm{PCl}$ and $\mathrm{OMT}$ therapy in patients with CTO. Results stated that PCl could improve survival and reduce MACE, which are not consistence with our results. That may be interpreted that more studies were included in our study with a significant greater population. 4 out of 11 studies included in our analysis are RCTs, which is not included in Ma et al study ${ }^{[30]}$. EXPLORE trial ${ }^{[31]}$ suggested that PCI for patients with STEMI concurrent CTO in non-IRA could not significantly reduce MACE compared with OMT. In addition, IMPACTOR-CTO trial[21] also supported that. These evidences support our results.

Recently DECISION-CTO trial ${ }^{[19]}$, an open-label multicenter RCT from Korea, recruited 834 patients with CTO who were randomly assigned to PCI and no PCI arms. Results of DECISION-CTO trial showed that there was no difference in the incidence of clinical outcomes. This was contrast with our results. However, Chandrasekhar et al ${ }^{[32]}$ study claimed that patients in Asians experienced higher rates of cardiac death than whom in European after PCl, which was keeping with our results. Some reasons may account for the association of $\mathrm{PCl}$ and lower cardiac death from our results. One reason may be that PCl can improve perfusion of myocardium, relieve ischemic burden and reverse ventricular remolding ${ }^{[33,34]}$, which lead to an improvement of LVEF, and then can avoid deterioration of cardiac function. Previous study indicated that low LVEF is associate with higher risk of cardiac death ${ }^{[35]}$. The other reason is that PCI can decrease risk of ventricular arrhythmia ${ }^{[6,36]}$, which increase the occurrence of cardiac sudden death.

Interestingly, subgroup analysis of our study reminds us that ethnic discrepancy exist in MACE and cardiac death. Benefits from CTO patients receiving PCI therapy are in favor of Caucasian. Before that, some studies also illustrated the ethnic discrepancy between Asian and Caucasian. Zaman et al ${ }^{\left[{ }^{[3]}\right.}$ found that $\mathrm{PCl}$ can improve angina symptoms, which prefer to Caucasian compared Asian (60.3\% vs. 43.6\%). Slater et al ${ }^{[38]}$ also figured out an ethnic difference in clinical outcomes. One year mortality differed in Caucasian and Asian after $\mathrm{PCl}$ (7.9\% vs. 5.1\%). Aforementioned evidence supported our results.

Many reasons may explain out results. Firstly, some studies show that diabetes mellitus, hypercholesterolemia ${ }^{[39]}$ and smoking ${ }^{[40]}$ are common in Asian. These factors contribute to the worse outcomes of Asian. Secondly, European compliance and medication after discharge are better than Asian ${ }^{[40]}$. Thirdly, the program of cardiac rehabilitation was done better in European than Asian ${ }^{[41,42]}$. Lastly, there was a ethnic discrepancy in response to clopidogrel antiplatelet therapy for patients with CAD. As process of clopidogrel metabolizing to its active substance requires the CYP2C19 enzyme, and gene mutation of CYP2C19, which would lead to the dysfunction of the enzyme, is higher in Asian compared with Western patients ${ }^{[43]}$. So Asian patients with CAD are lower response to clopidogrel, which is associated with worse outcomes, especially after PCl. Generally ethnic discrepancies reflect the difference in gene, life habit, hospital medical care and so on.

\section{Limitation]}

First, the number of studies is relatively small, and the number of studies about west European population is relatively small, which may hamper the statistical power of assessing the association of ethnicity and outcomes. More studies are needed to investigate the association of ethnicity and outcomes. Second, our study dose not explore the relation of CTO in different locations and outcomes. A study indicated that PCI was associates with improved long-term survival in patients with CTO of LAD ${ }^{[44]}$. Third, our study dose not assess whether PCl can ameliorate quality of life for CTO patients or not. Last, studies included in our analysis do not report economic data, so that we can not explore the cost-effect relationship. In the future, more studies are required to explore the cost-effect relationship.

\section{Conclusion:}

Compared with OMT, PCI is associated with significant reduction of cardiac death, however, without significant difference in MACE, MI, repeated revascularization and stroke. Sub-analysis indicates that $\mathrm{PCl}$ is favor of West European because it can reduce risk of MACE and cardiac death.

\section{Abbreviations}

PCI『percutaneous coronary intervention; OMT囚optimal medical therapy $₫$ CTO囚chronic total occlusion; RCTs: Randomized controlled trials; MACE: major adverse cardiovascular events; STEMI: ST-segment elevation myocardial infarction; PRISMA: Preferred reporting items for systematic reviews and meta- 


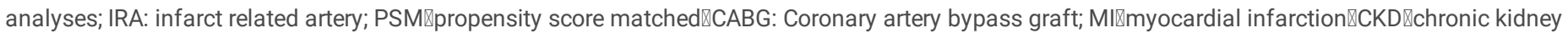
disease; LVEF: Left ventricular ejection fraction; CAD: Coronary artery disease; LAD囚left anterior descending artery;

\section{Declarations}

\section{Ethics approval and consent to participate}

This work is a systemic review and meta-analysis, Ethics approval and consent to participate is not applicable.

\section{Consent for publication}

All authors approve the consent for publication.

\section{Availability of data and material}

The dataset supporting the conclusions of this article is included within the article.

\section{Competing interests}

The authors declared that there is no competing interest.

\section{Funding}

The work did not accept any kind of economic support.

\section{Authors' contributions}

FL Z, N W, and DL J designed the study. MZ L and LF S performed and collected the data. FL Z, QS L, and MZ L analyzed the data. FL Z and DL J wrote the manuscript. All authors approved the contents of the manuscript.

\section{Acknowledgements}

The authors would like to thank Huimin Yang PhD. and Hang Yu PhD. (Department of Cardiology, the first affiliated hospital of China Medical University.) for grammatical assistance and study research.

\section{References}

1. Fefer P, Knudtson M L, Cheema A N, et al. Current perspectives on coronary chronic total occlusions: the Canadian Multicenter Chronic Total Occlusions Registry. J Am Coll Cardiol. 2012;59(11):991-997.

2. Azzalini L, Jolicoeur E M, Pighi M, et al. Epidemiology, Management Strategies, and Outcomes of Patients With Chronic Total Coronary Occlusion. Am J Cardiol. 2016;118(8):1128-1135.

3. Jeroudi O M, Alomar M E, Michael T T, et al. TCT-357 Prevalence and Management of Coronary Chronic Total Occlusions in a Tertiary Veterans Affairs Hospital. Journal of the American College of Cardiology. 2013;62(18, Supplement 1):B113

4. Allahwala U K, Jolly S S, Džavík V, et al. The Presence of a CTO in a Non-Infarct-Related Artery During a STEMI Treated With Contemporary Primary PCI Is Associated With Increased Rates of Early and Late Cardiovascular Morbidity and Mortality: The CTO-TOTAL Substudy. JACC: Cardiovascular Interventions. 2018;11(7):709-711.

5. Fefer P, Knudtson M L, Cheema A N, et al. Current perspectives on coronary chronic total occlusions: the Canadian Multicenter Chronic Total Occlusions Registry. J Am Coll Cardiol. 2012;59(11):991-997.

6. Nombela-Franco L, lannaccone M, Anguera I, et al. Impact of Chronic Total Coronary Occlusion on Recurrence of Ventricular Arrhythmias in Ischemic Secondary Prevention Implantable Cardioverter-Defibrillator Recipients (VACTO Secondary Study): Insights From Coronary Angiogram and Electrogram Analysis. JACC Cardiovasc Interv. 2017;10(9):879-888.

7. Brilakis E S, Banerjee S, Karmpaliotis D, et al. Procedural Outcomes of Chronic Total Occlusion Percutaneous Coronary Intervention: A Report From the NCDR (National Cardiovascular Data Registry). JACC: Cardiovascular Interventions. 2015;8(2):245-253.

8. Karmpaliotis D, Lembo N, Kalynych A, et al. Development of a high-volume, multiple-operator program for percutaneous chronic total coronary occlusion revascularization: procedural, clinical, and cost-utilization outcomes. Catheter Cardiovasc Interv.2013;82(1):1-8.

9. Tsai T T, Stanislawski M A, Shunk K A, et al. Contemporary Incidence, Management, and Long-Term Outcomes of Percutaneous Coronary Interventions for Chronic Coronary Artery Total Occlusions: Insights From the VA CART Program. JACC Cardiovasc Interv. 2017;10(9):866-875. 
10. Neumann F J, Sousa-Uva M, Ahlsson A, et al. 2018 ESC/EACTS Guidelines on myocardial revascularization. Eurolntervention. 2019;14(14):1435-1534.

11. G N, De Felice F, F B, et al. Late (3 years) follow-up of successful versus unsuccessful revascularization in chronic total coronary occlusions treated by drug eluting stent. The American journal of cardiology. 2012;110(7):948-953.

12. A T, M G, J M, et al. Survival after percutaneous coronary intervention for chronic total occlusion. Clinical research in cardiology: official journal of the German Cardiac Society. 2016;105(11):921-929.

13. F B, N V, O A, et al. Improved cardiac survival, freedom from MACE and angina-related quality of life after successful percutaneous recanalization of coronary artery chronic total occlusions. International journal of cardiology. 2012;161(1):31-38.

14. BK K, S S, DH S, et al. Clinical outcome of successful percutaneous coronary intervention for chronic total occlusion: results from the multicenter Korean Chronic Total Occlusion (K-CTO) registry. The Journal of invasive cardiology. 2014;26(6):255-259.

15. Werner G S, Martin-Yuste V, Hildick-Smith D, et al. A randomized multicentre trial to compare revascularization with optimal medical therapy for the treatment of chronic total coronary occlusions. Eur Heart J. 2018;39(26):2484-2493.

16. Ladwiniec A, Allgar V, Thackray S, et al. Medical therapy, percutaneous coronary intervention and prognosis in patients with chronic total occlusions. Heart. 2015;101(23):1907-1914.

17. Tomasello S D, Boukhris M, Giubilato S, et al. Management strategies in patients affected by chronic total occlusions: results from the Italian Registry of Chronic Total Occlusions. Eur Heart J. 2015;36(45):3189-3198.

18. Yang J H, Kim B S, Jang W J, et al. Optimal Medical Therapy vs. Percutaneous Coronary Intervention for Patients With Coronary Chronic Total Occlusion A Propensity-Matched Analysis. Circ J. 2016;80(1):211-217.

19. Lee S W, Lee P H, Ahn J M, et al. Randomized Trial Evaluating Percutaneous Coronary Intervention for the Treatment of Chronic Total Occlusion. Circulation. 2019;139(14):1674-1683.

20. Guo L, Zhong L, Chen K, et al. Long-term clinical outcomes of optimal medical therapy vs. successful percutaneous coronary intervention for patients with coronary chronic total occlusions. Hellenic J Cardiol. 2018;59(5):281-287.

21. Obedinskiy A A, Kretov E I, Boukhris M, et al. The IMPACTOR-CTO Trial. JACC Cardiovasc Interv. 2018;11(13):1309-1311.

22. Moher D, Liberati A, Tetzlaff J, et al. Preferred reporting items for systematic reviews and meta-analyses: the PRISMA statement. BMJ. 2009;339:b2535.

23. Stang A. Critical evaluation of the Newcastle-Ottawa scale for the assessment of the quality of nonrandomized studies in meta-analyses. Eur $\mathrm{J}$ Epidemiol. 2010;25(9):603-605.

24. Weintraub W S, Spertus J A, Kolm P, et al. Effect of PCI on quality of life in patients with stable coronary disease. N Engl J Med. 2008;359(7):677-687.

25. Pursnani S, Korley F, Gopaul R, et al. Percutaneous coronary intervention versus optimal medical therapy in stable coronary artery disease: a systematic review and meta-analysis of randomized clinical trials. Circ Cardiovasc Interv. 2012;5(4):476-490.

26. Gao L, Wang Y, Liu Y, et al. Long-term clinical outcomes of successful revascularization with drug-eluting stents for chronic total occlusions: A systematic review and meta-analysis. Catheter Cardiovasc Interv. 2017;89(S1):574-581.

27. Patel V G, Brayton K M, Tamayo A, et al. Angiographic success and procedural complications in patients undergoing percutaneous coronary chronic total occlusion interventions: a weighted meta-analysis of 18,061 patients from 65 studies. JACC Cardiovasc Interv. 2013;6(2):128-136.

28. Jones D A, Weerackody R, Rathod K, et al. Successful recanalization of chronic total occlusions is associated with improved long-term survival. JACC Cardiovasc Interv. 2012;5(4):380-388.

29. Galassi A R, Sianos G, Werner G S, et al. Retrograde Recanalization of Chronic Total Occlusions in Europe: Procedural, In-Hospital, and Long-Term Outcomes From the Multicenter ERCTO Registry. J Am Coll Cardiol. 2015;65(22):2388-2400.

30. Ma Y, Li D, Li J, et al. Percutaneous coronary intervention versus optimal medical therapy for patients with chronic total occlusion: a meta-analysis and systematic review. J Thorac Dis. 2018;10(5):2960-2967.

31. Henriques J P, Hoebers L P, Ramunddal T, et al. Percutaneous Intervention for Concurrent Chronic Total Occlusions in Patients With STEMI: The EXPLORE Trial. J Am Coll Cardiol. 2016;68(15):1622-1632.

32. Chandrasekhar J, Kalkman D N, Aquino M B, et al. 1-year results after PCI with the COMBO stent in all-comers in Asia versus Europe: Geographical insights from the COMBO collaboration. Int J Cardiol. 2020.

33. Pavlovic S V, Sobic-Saranovic D P, Beleslin B D, et al. One-year follow-up of myocardial perfusion and function evaluated by gated SPECT MIBI in patients with earlier myocardial infarction and chronic total occlusion. Nucl Med Commun. 2009;30(1):68-75.

34. Bucciarelli-Ducci C, Auger D, Di Mario C, et al. CMR Guidance for Recanalization of Coronary Chronic Total Occlusion. JACC Cardiovasc Imaging. 2016;9(5):547-556.

35. AJ M, WJ H, DS C, et al. Improved survival with an implanted defibrillator in patients with coronary disease at high risk for ventricular arrhythmia. Multicenter Automatic Defibrillator Implantation Trial Investigators. The New England journal of medicine. 1996;335(26):1933-1940.

36. Cetin M, Zencir C, Cakici M, et al. Effect of a successful percutaneous coronary intervention for chronic total occlusion on parameters of ventricular repolarization. Coron Artery Dis. 2014;25(8):705-712.

37. Zaman M J, Crook A M, Junghans C, et al. Ethnic differences in long-term improvement of angina following revascularization or medical management: a comparison between south Asians and white Europeans. J Public Health (Oxf). 2009;31(1):168-174.

38. J S, F S, S D, et al. Ethnic differences in the presentation, treatment strategy, and outcomes of percutaneous coronary intervention (a report from the National Heart, Lung, and Blood Institute Dynamic Registry). The American journal of cardiology. 2003;92(7):773-778. 
39. Klomp M, Damman P, Beijk M A, et al. Differences in cardiovascular risk factors and clinical outcomes between Western European and Southeast Asian patients treated with the Genous Bio-engineered R stent: an e-HEALING worldwide registry substudy. Coron Artery Dis. 2012;23(4):271-277.

40. Gijsberts C M, Seneviratna A, Hoefer I E, et al. Inter-Ethnic Differences in Quantified Coronary Artery Disease Severity and All-Cause Mortality among Dutch and Singaporean Percutaneous Coronary Intervention Patients. PLoS One. 2015;10(7):e131977.

41. Tod A M, Wadsworth E, Asif S, et al. Cardiac rehabilitation: the needs of South Asian cardiac patients. Br J Nurs. 2001;10(16):1028-1033.

42. Jolly K, Greenfield S M, Hare R. Attendance of ethnic minority patients in cardiac rehabilitation. J Cardiopulm Rehabil. 2004;24(5):308-312.

43. Bae J S, Ahn J H, Tantry U S, et al. Should Antithrombotic Treatment Strategies in East Asians Differ from Caucasians? Curr Vasc Pharmacol. 2018;16(5):459-476.

44. JH A, JH Y, YB S, et al. Impact of Chronic Total Coronary Occlusion Location on Long-term Survival After Percutaneous Coronary Intervention. Revista espanola de cardiologia (English ed.). 2019;72(9):717-723.

\section{Figures}

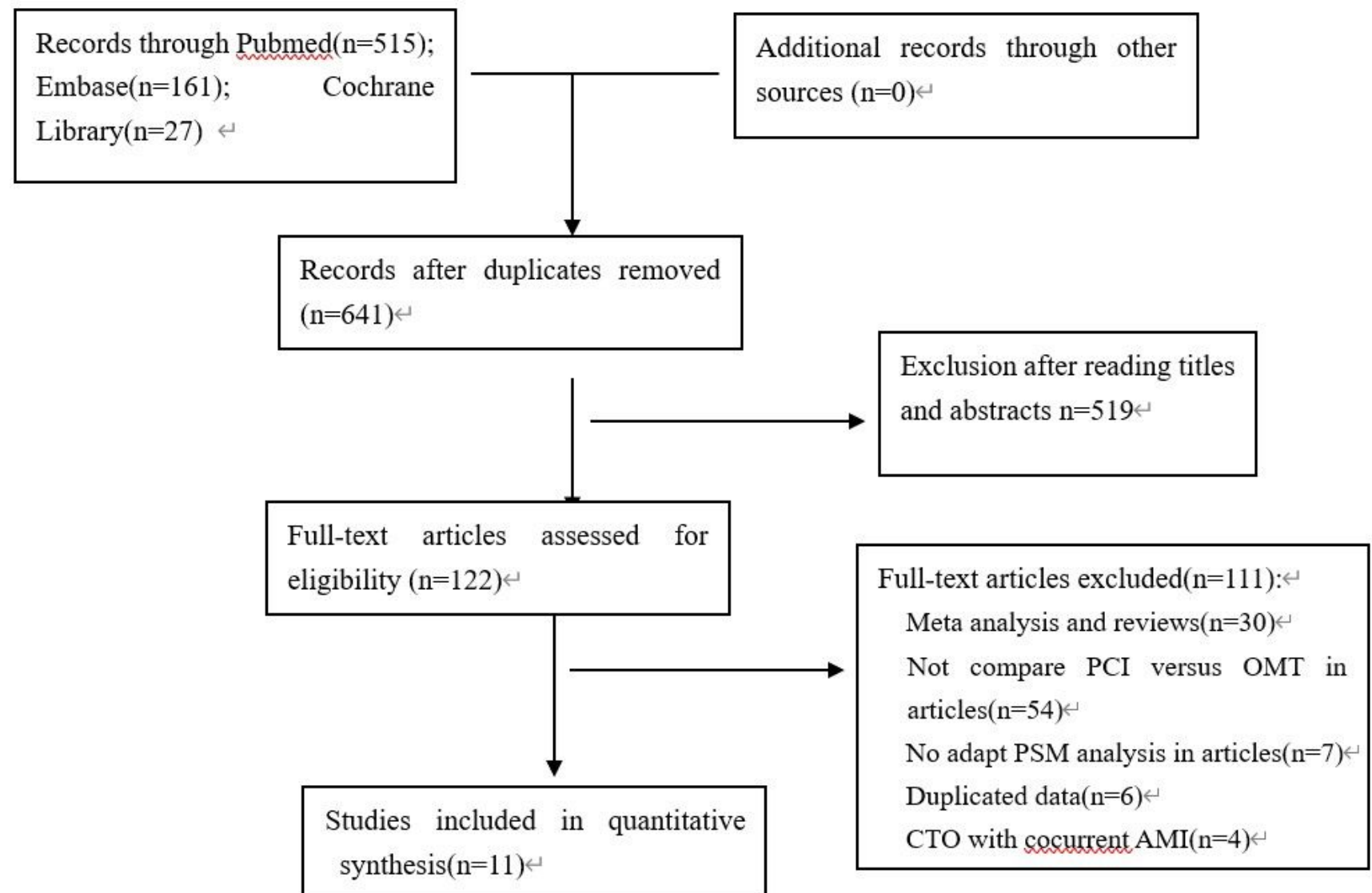

Fig1. PRISMA diagram

\section{Figure 1}

Study selection procedure was detailedly proscribed in Fig1 
$\begin{array}{llll}\text { CTO-PCl CTO-OMT Risk Ratio } & \text { Risk Ratio }\end{array}$

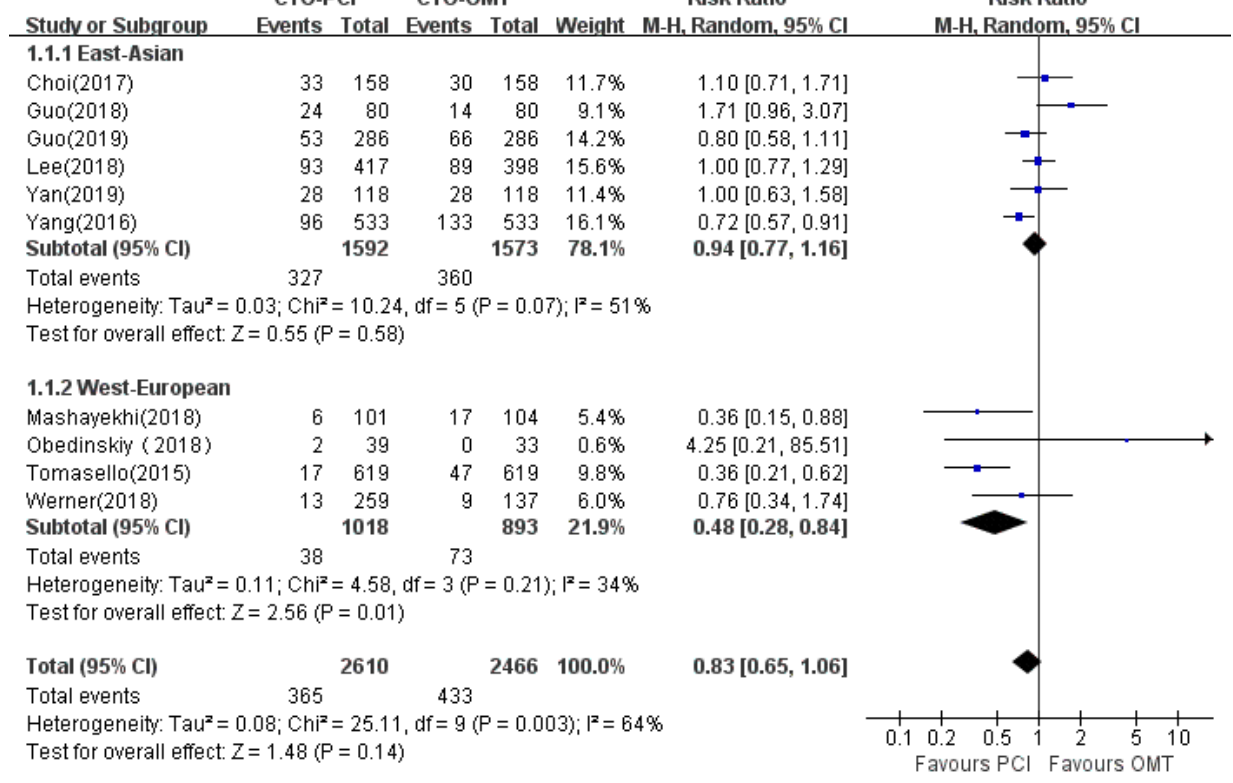

\section{Figure 2}

Forest plot of MACE

\begin{tabular}{|c|c|c|c|c|c|c|c|c|c|}
\hline Study or Subgroup & \multicolumn{2}{|c|}{ CTO-PCI } & \multicolumn{2}{|c|}{ сто-омт } & Weight & $\begin{array}{l}\text { Risk Ratio } \\
\text { M-H, Fixed, } 95 \% \mathrm{Cl}\end{array}$ & \multicolumn{3}{|c|}{$\begin{array}{c}\text { Risk Ratio } \\
\text { M-H, Fixed, } 95 \% \mathrm{Cl}\end{array}$} \\
\hline \multicolumn{10}{|l|}{ 1.2.1 East-Asian } \\
\hline Choi(2017) & 2 & 158 & 5 & 158 & $3.7 \%$ & $0.40[0.08,2.03]$ & & & - \\
\hline Guo(2018) & 9 & 80 & 6 & 80 & $4.4 \%$ & $1.50[0.56,4.02]$ & & & \\
\hline Guo(2019) & 9 & 286 & 17 & 286 & $12.4 \%$ & $0.53[0.24,1.17]$ & & & \\
\hline Lee(2018) & 8 & 417 & 14 & 398 & $10.5 \%$ & $0.55[0.23,1.29]$ & & & \\
\hline $\operatorname{Yan}(2019)$ & 6 & 118 & 11 & 118 & $8.0 \%$ & $0.55[0.21,1.43]$ & & & \\
\hline Yang(2016) & 31 & 533 & 44 & 533 & $32.1 \%$ & $0.70[0.45,1.10]$ & & & \\
\hline Subtotal $(95 \% \mathrm{Cl})$ & & 1592 & & 1573 & $71.1 \%$ & $0.67[0.49,0.90]$ & & & \\
\hline Total events & 65 & & 97 & & & & & & \\
\hline \multicolumn{10}{|c|}{ Heterogeneity: $\mathrm{Chi}^{2}=3.75, \mathrm{df}=5(\mathrm{P}=0.59) ; \mathrm{I}^{2}=0 \%$} \\
\hline \multicolumn{10}{|c|}{ Test for overall effect: $Z=2.61(P=0.009)$} \\
\hline \multicolumn{10}{|l|}{ 1.2.2 West-European } \\
\hline Ladwiniec(2015) & 5 & 177 & 12 & 177 & $8.8 \%$ & $0.42[0.15,1.16]$ & & & \\
\hline Tomasello(2015) & 9 & 619 & 27 & 619 & $19.7 \%$ & $0.33[0.16,0.70]$ & & $\longrightarrow$ & \\
\hline Werner(2018) & 2 & 259 & 0 & 137 & $0.5 \%$ & $2.65[0.13,54.89]$ & & & \\
\hline Subtotal $(95 \% \mathrm{Cl})$ & & 1055 & & 933 & $28.9 \%$ & $0.40[0.22,0.71]$ & & & \\
\hline Total events & 16 & & 39 & & & & & & \\
\hline \multirow{2}{*}{\multicolumn{10}{|c|}{$\begin{array}{l}\text { Heterogeneity: } C h i^{2}=1.73, d f=2(P=0.42) ;\left.\right|^{2}=0 \% \\
\text { Test for overall effect: } Z=3.13(P=0.002)\end{array}$}} \\
\hline & & & & & & & & & \\
\hline Total $(95 \% \mathrm{Cl})$ & & 2647 & & 2506 & $100.0 \%$ & $0.59[0.45,0.77]$ & & $\boldsymbol{\gamma}$ & \\
\hline Total events & 81 & & 136 & & & & & & \\
\hline \multicolumn{7}{|c|}{ Heterogeneity: $\mathrm{Chi}^{2}=8.05, \mathrm{df}=8(\mathrm{P}=0.43) ; \mathrm{I}^{2}=1 \%$} & 0.01 & & \\
\hline \multicolumn{7}{|c|}{ Test for overall effect: $Z=3.88(P=0.0001)$} & \multicolumn{3}{|c|}{$\begin{array}{cccc}0.1 & 1 & 10 & 100 \\
\text { Favours } \mathrm{PCl} & \text { Favours OMT }\end{array}$} \\
\hline
\end{tabular}

\section{Figure 3}

Forest plot of Cardiac death 
$\begin{array}{llll}\text { CTO-PCI CTO-OMT } & \text { Risk Ratio } & \text { Risk Ratio }\end{array}$

Study or Subgroup Events Total Events Total Weight M-H, Fixed, 95\% Cl M-H, Fixed, 95\% C

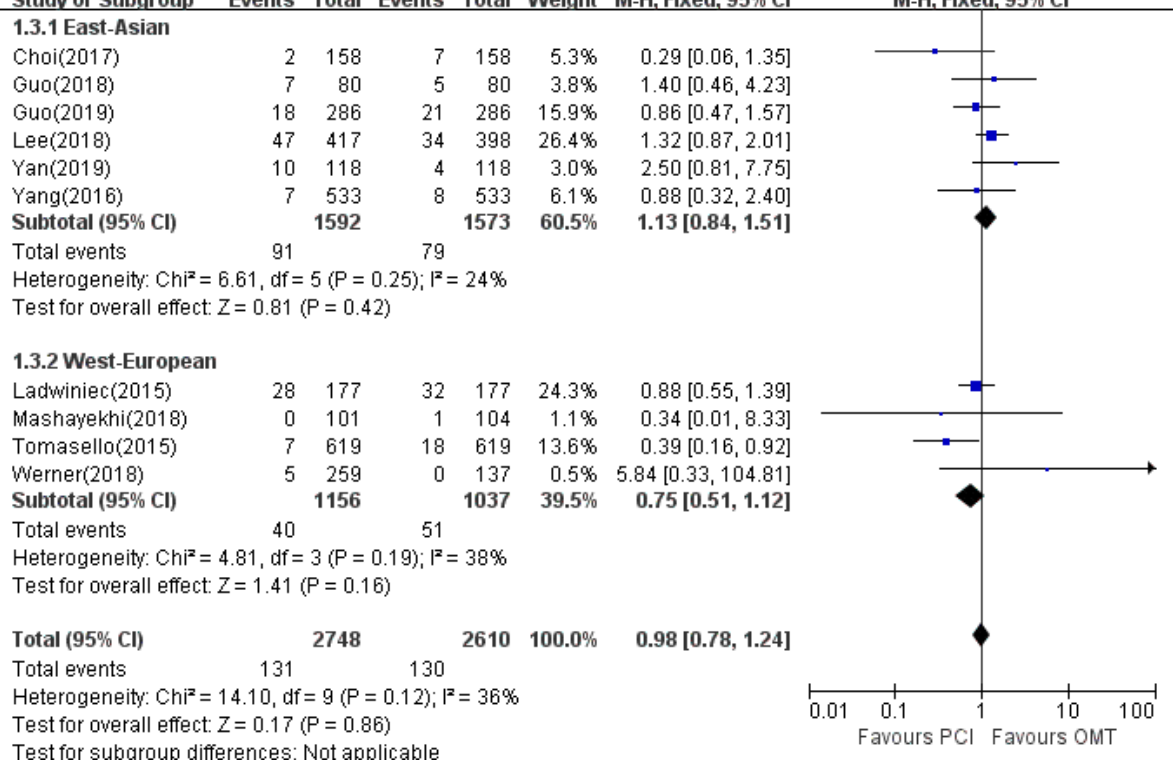

Test for subaroun differences: Not anplicable

Figure 4

Forest plot of Myocardial infarction

CTO-PCI CTO-OMT

Risk Ratio

Risk Ratio

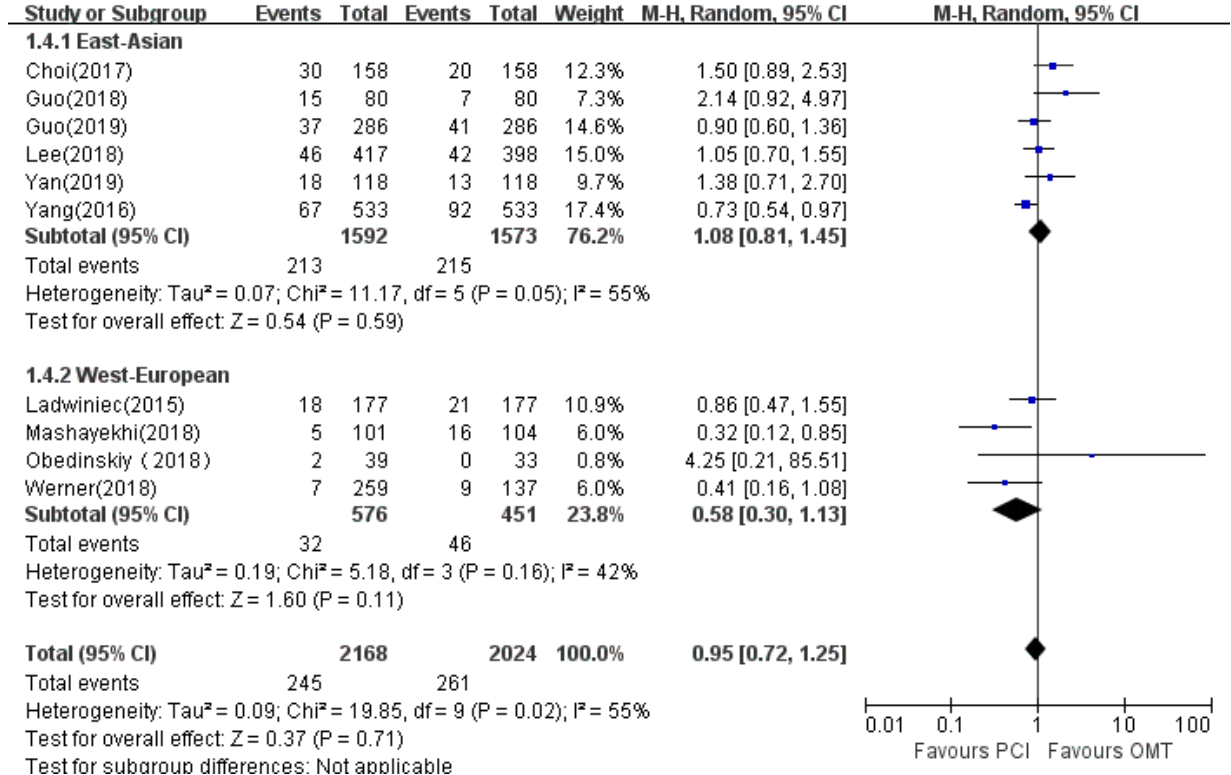

\section{Figure 5}

Forest plot of Repeat Revascularization 
$\begin{array}{llll}\text { CTO-PCl CTO-OMT } & \text { Risk Ratio } & \text { Risk Ratio }\end{array}$

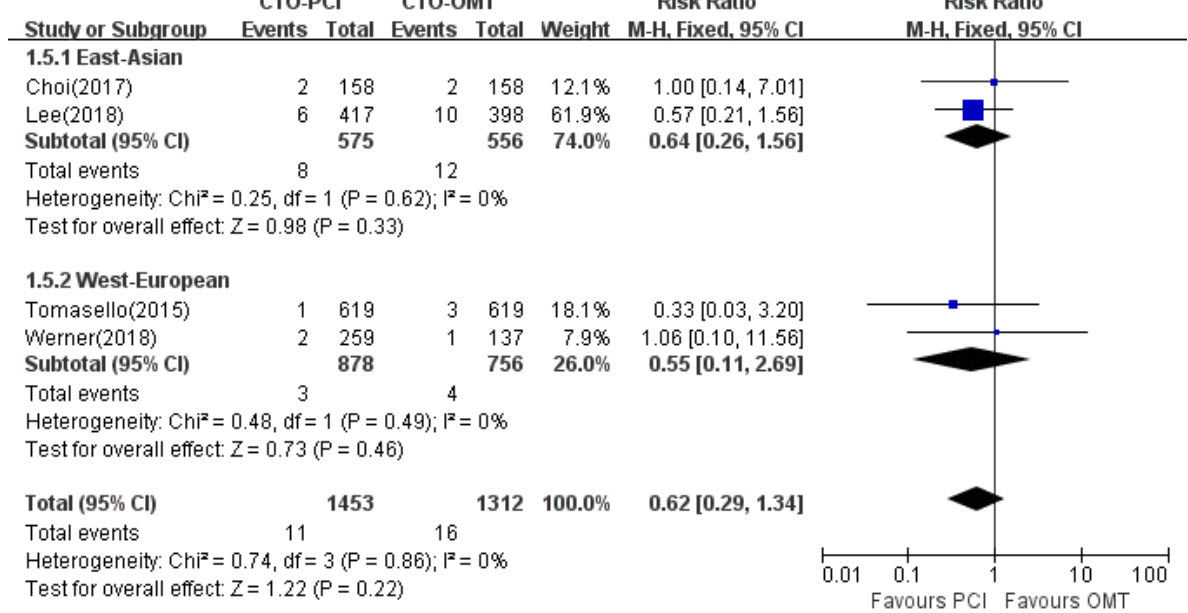

\section{Figure 6}

\section{Forest plot of Stroke}

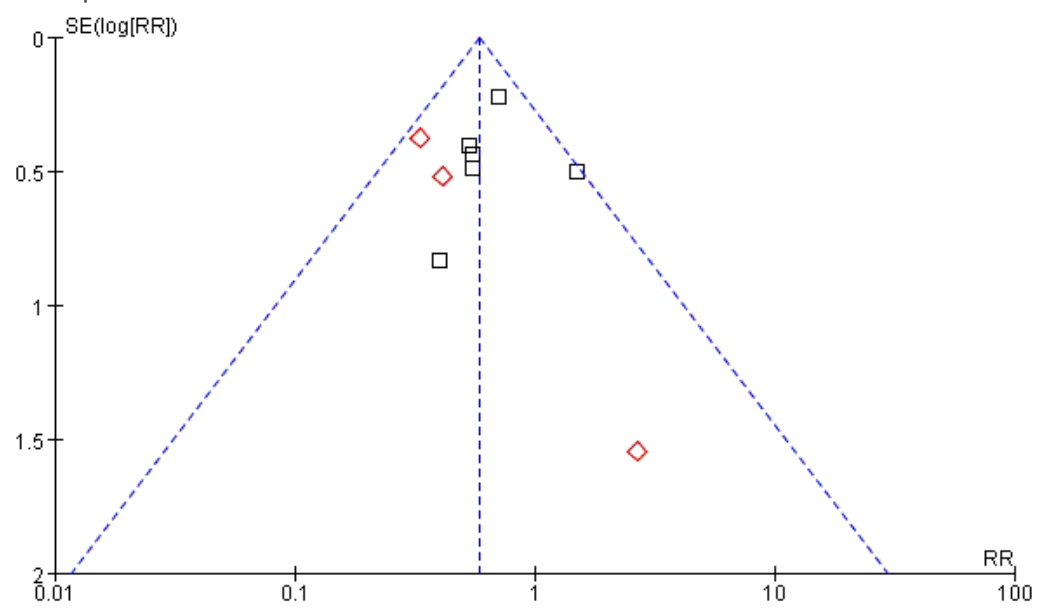

Subgroups

$\checkmark$ West-European

\section{Figure 7}

Funnel plot of Cardiac death

\section{Supplementary Files}

This is a list of supplementary files associated with this preprint. Click to download.

- Supplement1.doc

- Supplement2.doc 